Check for updates

The BMJ

kabbasi@bmi.com Follow Kamran on Twitter@KamranAbbasi Cite this as: $B M / 2021 ; 373: n 1275$ http://dx.doi.org/10.1136/bmj.n1275 Published: 20 May 2021

\title{
Covid-19: Why prioritising prevention matters in a pandemic of cures
}

\section{Kamran Abbasi executive editor}

Prevention is better than cure. Simple. Clear. Logical. Except that it is easily overcomplicated, clouded, and misplaced. When we forget that prevention is better than cure, primary care becomes an easy scapegoat, even though the pandemic has reinforced its importance in improving baseline population health, reducing health inequalities, delivering a vaccination strategy, and keeping people out of hospital.

We might forget the mammoth efforts of general practice to reconfigure care-and then reverse some of that reconfiguration ${ }^{12}$-the extra burden and complexity created by limitless digital access of patients to health professionals, ${ }^{3}$ and the ingenuity and partnership now needed between primary and secondary care to clear a 4.7 million person waiting list with £16om of innovation funding. ${ }^{4}$ Or that preventing racism in general practice and in hospitals, in doctors' education, training, assessment, and disciplinary procedures, is better for patients, an issue that the UK's General Medical Council is now promising to tackle head on. ${ }^{5}$

We might forget that the accelerated achievements of the vaccination programme, supported by new evidence of effectiveness of rollout and dose spacing, $7^{-9}$ are built on firm experience of vaccine development and are unlikely to translate to the political folly of promising antivirals for people to use at home by the end of 2021. ${ }^{10}$ Our political loyalties might further blind us to the damage to people's health caused by the political elite brokering pandemic contracts for the personal gain of unqualified friends and business associates. ${ }^{11}$

We might forget to consider local public health voices, for instance those calling for surge vaccination in response to a worrying rise in cases of the new variant of concern B.1.617.2 in Bolton, Blackburn, and around the world. ${ }^{12}$ We might choose to overlook failures in protecting international borders to encourage trade deals and instead blame the populations most at risk from state blunders without understanding the complexities of vaccine hesitancy and the substantial global evidence on its causes, consequences, and solutions. ${ }^{13}$

In our vaccine euphoria we might forget our responsibilities to support vaccine patent waivers and prevent infections around the world-one benefit of which will be less cure at home-by creating a vaccine apartheid that indulges 1.5 billion excess doses in rich countries while a mere $0.3 \%$ of doses are delivered to low income countries. ${ }^{14}$ We might forget the value of international solidarity and equity ${ }^{15}$ and the persistent unpreparedness and political hesitancy that leaves the world as vulnerable to the next pandemic as it was 18 months ago. ${ }^{16}$

Our corporate blindness, such as among wealthy benefactors like the Wellcome Trust and Gates
Foundation, might prevent us from seeing the damage we are causing to the planet and to health, a climate emergency that will outlast the pandemic, by retaining investments in fossil fuel companies, receiving state subsidies for "intangible drilling," and failing to back climate ambitions to disinvest with sufficient actions and money. ${ }^{17}$

Prevention, then, is better than cure-but its value is easier to forget and takes longer to realise.

Salisbury H. Helen Salisbury: GPs deserve better than this micromanagement. BMJ2021;373:n1256doi: 10.1136/bmi.n1256.

2 lacobucci G. GPs should return to offering face-to-face appointments without prior triage, says NHS. BM/2021;373:n1251. doi: 10.1136/bmi.n1251 pmid: 33990340

3 Mathew R. Rammya Mathew: Digital access has opened the floodgates to patient demand. BMJ2021;373:n1246doi: 10.1136/bmj.n1246.

4 lacobucci G. Covid-19: NHS to trial rapid diagnostics and Saturday clinics to tackle elective care backlog. BMJ2021;373:n1243. doi: 10.1136/bmi.n1243 pmid: 33985984

5 lacobucci G. GMC sets targets to end disproportionate complaints against ethnic minority doctors. BMJ2021;373:n1269doi: 10.1136/bmj.n1269.

6 lacobucci G. GPs should be able to delist patients who racially abuse staff, say leaders. BM/2021;373:n1240. doi: 10.1136/bmj.n1240 pmid: 33985994

7 Lopez Bernal J, Andrews N, Gower C, etal. Effectiveness of the Pfizer-BioNTech and Oxford-AstraZeneca vaccines on covid-19 related symptoms, hospital admissions, and mortality in older adults in England: test negative case-control study. BMJ2021;373:n1088. doi: 10.1136/bmi.n1088 pmid: 33985964

8 Lisewski AM. Effectiveness of England's initial vaccine roll out. BMJ 2021;373:n1201. doi: 10.1136/bmi.n1201 pmid: 33985966

9 Romero-Brufau S, Chopra A, Ryu AJ, etal. Public health impact of delaying second dose of BNT162b2 or mRNA-1273 covid-19 vaccine: simulation agent based modeling study. BMJ2021;373:n1087 doi: 10.1136/bmj.n1087 pmid: 33980718

10 Smith D, Gill D. Antivirals against SARS-CoV-2 by autumn?BMJ 2021;373:n1215. doi: 10.1136/bmi.n1215 pmid: 34001499

11 Cowper A. What doctors need to know about the Greensill scandal. BMJ 2021:373:n1245. doi: 10.1136/bmi.n1245 pmid: 33990341

12 Wise J. Covid-19: Second vaccine doses expedited in areas of England where new variant is high. BM/2021;373:n1266 doi: 10.1136/bmj.n1266 pmid: 34001501

13 Razai MS, Chaudhry UAR, Doerholt K, Bauld L, Majeed A. Covid-19 vaccination hesitancy. BMJ2021;373:n1138.

14 Gonsalves G, Yamey G. The covid-19 vaccine patent waiver: a crucial step towards a "people's vaccine". BM/2021;373:n1249. doi: 10.1136/bmi.n1249 pmid: 34001498

15 Bump JB, Friberg P, Harper DR. International collaboration and covid-19: what are we doing and where are we going?BM/2021;372:n180. doi: 10.1136/bmj.n180 pmid: 33509953

16 Wise J. Covid-19: Global response was too slow and leadership absent report finds. BM/2021;373:n1234. doi: 10.1136/bmj.n1234 pmid: 33985967

17 Schwab T. How Wellcome's opaque fossil fuel investments harm its global health mission. BMJ2021;373:n1202doi: 10.1136/bmj.n1202.

This article is made freely available for use in accordance with BMJ's website terms and conditions for the duration of the covid-19 pandemic or until otherwise determined by BMJ. You may use, download and print the article for any lawful, non-commercial purpose (including text and data mining) provided that all copyright notices and trade marks are retained. 